\title{
Energy Balance and Population Structure of Elk (Cervus elaphus nelsoni Nelson, 1902) in Banff National Park ${ }^{1}$
}

\author{
Bogusław BOBEK ${ }^{2}$, Rick KUNELIUS \& January WEINER
}

\begin{abstract}
Bobek B., Kunelius R. \& Weiner J., 1983: Energy balance and population structure of elk (Cervus elaphus nelsoni Nelson, 1902) in Banff National Park. Acta theriol., 28, 17: 259-272 [With 1 Table \& 4 Figs.]

A model of the energy budget for wapiti (Cervus elaphus nelsoni Nelson, 1902) was formulated, allowing comparison of energy requirements and energy consumption which varied throughout the year with the quality of available food. The total yearly energy requirements of male and female wapiti were estimated to be 3,089 and 3,568 Mcal, respectively. Potential elk food plants in Banff National Park were collected during the growing season and in winter. These were analyzed for crude protein, ether extract, ash, cell wall content (CWC), acid detergent lignin $(A D L)$ and acid detergent fiber $(A D F)$. Browse was nutritionally poorer than non-browse food. A simulation of body weight changes for both sexes of wapiti was carried out using the simulation model and food quality data. With a predominance of browse in the diets the model predicts a drastic reduction in body weight, embryo re-absorption, and eventual death of adult animals. The influence of snow cover on sex ratio and reproductive success (calf/female ratio) of elk living in Banff National Park is discussed and explained in relation to consequent changes in nutritional balance.

[Faculty of Environmental Design, The University of Calgary, Alberta, Canada; Parks Canada, Banff National Park, Banff, Alberta, Canada (BB, RK); Department of Animal Ecology, Jagiellonian University, 30-060 Kraków, Karasia 5, Poland (JW)]
\end{abstract}

\section{INTRODUCTION}

At the turn of the 19th century wapiti nearly disappeared from the eastern slopes of the Canadian Rockies. The reintroduction of these animals was started in 1918 when animals were transported from Wyoming and Manitoba to Banff National Park, bringing the total population in 1920 to 251 individuals (Lloyd, 1927). The animals were gradually released and the population grew significantly so that according to nonrigorous censuses conducted by Green in 1943 (Green, unpubl.) and by Flook in 1963 (Flook, 1970) there were 1,136 and 2,679 animals respectively.

1 Supported in part by the University of Calgary, a Parks Canada grant to Dr. W. W. Ross and a grant to Dr. V. Geist.

2 Present address: Department of Animal Ecology, Jagiellonian University, Karasia 6, 30-060 Kraków, Poland. 
As the population grew, damage to aspen trees caused by the animals was observed. Especially severe was overbrowsing and bark stripping. Therefore beginning in 1941, population reduction programs were carried out. This continued until 1954, by which time the population had decreased and dropped below the carrying capacity of the habitat (Green, 1957). Reductions were reinitiated in 1957 and continued to 1969. At that time the program was discontinued since it appeared that the elk population in 1974 was about 30 animals and might be lost again from the área. During the reduction programs, 3,888 animals were shot. Presently population regrowth is occurring. According to park wardens there were 850 animals in 1977.

The demographic structure and population dynamics of this population has been described in many studies carried out in Banff National Park (Green, 1950; Flook 1970). All of them note that both sex ratio and calving success changed drastically from year to year. The intent of our work is to show how changes in individual energy balance can affect the demographic parameters of the population. The aim of this attempt is to explore a possible approach in the study of wildlife populations rather than to achieve ultimate and quantitatively accurate solutions.

\section{STUDY AREA}

Banff National Park is situated on the eastern slope of the Canadian Rocky Mountains in the province of Alberta covering an area of $6634 \mathrm{~km}^{2}$. Most of the park is comprised of subalpine forest regions and alpine tundra, but in areas at lower elevations there are areas dominated by Douglas fir (Pseudotsuga menziesii) and Lodgepole pine (Pinus contorta). For a description of plant communities of Banff National Park see Ogilvie, 1966.

\section{METHODS}

\subsection{Forage Quality}

Plants which were potential forage for elk were collected in August and December in Banff National Park. During the winter, all forages were collected by clipping. During the summer, browse was torn off by hand, imitating browsing by wapiti. Plant material was dried, then crude protein, ether extract and mineral content were determined. Cell wall content (CWC), acid detergent fiber ( $A D F$ ) and acid detergent lignin $(A D L)$ were estimated by detergent methods (Goering \& Van Soest, 1970). 


\subsection{Simulation of Energy Budgets}

Energy requirements of wapiti, calculated as a function of body weight, sex, season and life history information, were compared with energy intake which was estimated from the quality of food currently available. Changes in energy balance affect body energy reserves. Falling below an assumed lower limit of energy reserves induces reabsorption of the fetus in the females and eventually the death of adults (both sexes). Energy balance and weight changes were simulated using a difference equation model which operates at a six day time step.

To construct such model one should have many quantitative data and experimentally fitted equations describing the animals' functional responses. Such information for the elk is still not sufficient. To reduce the number of arbitrary assumptions the model was simplified.

The energy requirements of elk were estimated as the sum of fasting heat production (FHP), calorigenic effect of food (SDA), activity costs $(A C T)$, and reproductive costs (REP). Fasting heat production (Kcal $\times$ animal-1 $\times$ day $^{-1}$ ) was calculated as a function of body weight $(B W, \mathrm{~kg})$ :

$$
F H P=90.0 B W^{0.75}
$$

(Weiner, 1977: Gates \& Hudson, 1978).

For simplicity, SDA was assumed a constant, approximately $30 \%$ of $F H P$. Actually, SDA depends on the amount and quality of food eaten. The appropriate data for elk are lacking, but setting $S D A$ at a constant level should not markedly affect the final simulation results (Weiner, 1975a, b).

To estimate activity costs, the time budget of elk taken from Craighead et al. (1973) was used. The following values of metabolic increase in relation to FHP were assumed for different activity classes. Bedding $-0 \%$, standing $-23 \%$, feeding $-30 \%$, traveling $-40 \%$, traveling in snow $-100 \%$ (Weiner, 1977; Cohen et al., 1978; Gates \& Hudson, 1978). Additional costs of thermoregulation were ignored, since simulation of energy budgets of ruminants (e.g., roe deer (Capreolus capreolus: Weiner, 1975b), elk and mule deer (Odocoileus hemionus: Swift, Ellis \& Hoobs, 1980) as well as a detailed mathematical model of heat exchange between an elk and its environment (Weiner, unpubl.), have shown that these expenses are almost entirely compensated by the normal heat of metabolism (see also Moen, 1976).

The cost of reproduction was estimated for females only, assuming the pregnancy period to start September 18th with deliver on May 28th. Assuming body weight $(B W N)$ of new born wapiti to be $12 \mathrm{~kg}$ an exponential function was fitted to estimate fetal weight during the period of gestation $(B W N, \mathrm{~kg})$ :

$$
B W N=0.01 e^{0.02759 x}
$$

where $X$ is the day of pregnancy (Moen, 1973; Weiner, 1975b). On the basis of this equation daily production (PP), i.e., daily energy deposition in the fetus, was estimated, assuming the caloric value of fetal tissues to be $1.7 \mathrm{kcal} / \mathrm{g}$ fresh weight (Salomon-Legagneur, 1968; Weiner, 1975b). According to Graham (1965) and Rattray et al. (1974) it was assumed that the increase of respiration in pregnant females $\left(R P, \mathrm{kcal} \times \mathrm{animal}^{-1} \times \mathrm{day}^{-1}\right)$ is proportional to the weight of fetus:

$$
R P=82.0 B W N
$$

Such method of calculation has been proven to yield reliable results (Weiner, 1975b). Thus, the additional assimilation by pregnant females is the sum of $P P$ and $R P$.

To calculate the cost of lactation in females a growth curve for calves was 
used. This in conjunction with an estimate of calf's maintenance requirement permitted an estimate of its required energy intake. The body weight of a calf (BWC) during lactation period was approximated with equation based on a few data available for the growth rate of elk:

$$
B W C=9.46+0.86 X-0.00155 X^{2}
$$

where $B W C$ is body weight of a calf in $\mathrm{kg}, X$ is age in days.

This equation allows for reasonable predictions, however it is not statistically testable. Accordingly, the daily rate of biomass production ( $P C, \mathrm{kcal} \times \mathrm{animal}^{-1} \times$ $X$ day $\left.^{-1}\right)$ in terms of energy was estimated taking into account the caloric value of calves body weight increase equal $2.2 \mathrm{kcal} / \mathrm{g}$ of biomass (Rattray et al., 1973; Robbins et al., 1974). Using data on the metabolic rate of growing elk calves (Gates \& Hudson, 1978; Robbins et al., 1979; Gates \& Hudson pers. comm.) the calves' respiration ( $R \mathrm{C}$, kcal $\times$ animal $\left.{ }^{-1} \times \mathrm{day}^{-1}\right)$ was calculated from the following formula:

$$
R C=228.0 \quad B W C^{0.61}
$$

and the total assimilation of calves $\left(A S, \mathrm{kcal} \times \mathrm{animal}^{-1} \times \mathrm{day}^{-1}\right)$ :

$$
A S=P C+R C
$$

It is assumed here, that $R C$ contains maintenance metabolism as well as the metabolic cost of growth.

It was assumed, that the proportion of milk in a calf's diet drops linearly from $100 \%$ at the first day after birth to $0 \% 217$ days later. Assuming digestibility of milk to be $100 \%$ and efficiency of milk production in females to be $72 \%$ (Kielanowski, 1965; Hafez \& Dyer, 1969), the extra energy assimilation of a lactating female must be $A S / 0.72$. So calculated energetic effort of a female increases during the initial part of lactation period, reaches a peak some 10 weeks after parturition and gradually decreases thereafter. This pattern is very similar to the empirical findings in other cervids (Moen, 1973; Arman et al., 1974; Robbins \& Moen, 1975). The assumed body weight at birth and growth rate of elk calves is rather low, as compared to the range of available data. Thus, costs of reproduction in this model may be underestimated rather than overestimated.

The rate of energy consumption (voluntary food intake) in a grazing ruminant depends upon the digestibility of the food and ultimately on the chemical composition of the diet. The coefficient of digestibility is correlated with the content of different components of the diet (e.g., protein fiber, cellulose, lignin etc.). Appropriate qualitative studies on digestibility of food and voluntary food intake in relation to food composition for elk are lacking. Thus, functions used in this model are based upon scarce data concerning other wild ungulates. In this model, the lignin content (ADL) was arbitrarily chosen as an indicator of the potential digestibility of food. The following predictive function was derived from data on bison (Richmond, Hudson \& Christopherson, 1977) and roe deer (Perzanowski, 1978):

$$
D I G=82.0-2.3 \quad A D L
$$

where DIG is the digestibility coefficient $(\%)$ and $A D L$ is the percentage of lignin in CWC. This function has an intermediate slope compared to those for bison and roe deer and it gives reasonable predictions for an optimal diet composition. The rate of voluntary intake (VEI) was then estimated from the coefficient of digestibility (DIG). Since an appropriate empirical function for elk is lacking, the relation between VEI and DIG was fitted, based on data from roe deer (Staines, 1969; Maloiy \& Kay, 1971). The assumption was made that the voluntary intake of females has to be relatively higher than that of males, since the energy 
budget of the female includes the cost of reproduction. This assumption is supported by distinct morphological differences in the size of the digestive organs between the sexes of wild ruminants (Nagy \& Regelin, 1975). The slopes of linear functions predicting VEI from digestibility were taken from red deer regression

The intercepts for these equations were estimated by simulating the energy balance of both sexes using diet quality data representative of an "optimal": food mix according to Harper et al. (1969) The intercepts were modified until the body weight (for each sex) was identical at the beginning and the end of one annual cycle of the simulation. The following function resulted:

$$
V E I=a+4.848 \text { DIG }
$$

where $V E I=$ voluntary energy intake, $\mathrm{kcal} / \mathrm{kg}^{0.67} \times \mathrm{day}^{-1} \quad D I G=$ digestibility in percentage, $a=$ sex-specific parameter: -14.5 for male and +19.5 for females. The model could then be used to simulate the energy balance of animals consuming various diets, differing from the assumed "optimal" standard.

Energy balance was estimated by comparing simulated energy requirements with simulated energy assimilation from the available food. A positive energy balance causes an increase in energy reserves, while a negative balance results in decreased energy reserves and body weight.

Lean body weight for males and females were initialized at 250 and $200 \mathrm{~kg}$ respectively, with energy reserves at the beginning of the simulation (January 1) being set at 300,000 and $200,000 \mathrm{kcal}$ (approximately 30 and $20 \mathrm{~kg}$ of body fat). It was assumed that if energy reserves dropped to 30,000 kcal (approximately a $10 \%$ weight loss), a reabsorption of the fetus or cessation of lactation would occur in the female (Thorne et al., 1976) and if the energy reserves were completely exhausted ( $0 \mathrm{kcal})$, the animals would die, however, the simulation may continue beyond this point of assumed "death". Simulations were conducted using different hypothetical diets made up of components available for elk in Banff National Park.

\section{RESULTS}

\subsection{Forage Quality}

During the growing season both non-browse and browse food had similar percentages of crude protein and ash (Table 1). The food groups differed significantly in ether extract, $C W C$ and $A D F$, with non-browse foods having higher values. The mean percentage by dry weight of ADF was $6.8 \%$ for non-browse food and $8.9^{9} \%$ for browse. Astragalus frigidus, Shepardia canadensis and Oxytropis splendens were particularly rich in protein. Rosa acicularis and Delphinium glaucum had little fiber (Table 1).

During winter, browse had twice more $A D L$ and two times more ether extract than grasses and sedges. The two food groups had similar crude protein and $A D F$ contents: however, percentage of ash and $C W C$ was definitely greater in non-browse food (Table 1). Surprisingly little crude protein and $C W C$ was seen in aspen bark, however the level of 
Table 1

Nutritional values of plants collected in Banff National Park.

\begin{tabular}{|c|c|c|c|c|c|c|}
\hline Plant species & $\begin{array}{c}\text { Protein } \\
(\%)\end{array}$ & $\begin{array}{c}\text { Ether } \\
\text { extract } \\
(\%)\end{array}$ & $\begin{array}{l}\text { Ash } \\
(\%)\end{array}$ & $\begin{array}{c}C W C \\
(\%)\end{array}$ & $\begin{array}{c}A D F \\
(\% \text { of } \\
C W C)\end{array}$ & $\begin{array}{c}A D L \\
(\% \text { of } \\
C W C)\end{array}$ \\
\hline \multicolumn{7}{|c|}{ Summer 1976, non-browse food } \\
\hline Astragalus frigidus & 18.8 & 6.1 & 6.1 & 41.2 & 21.9 & 6.1 \\
\hline Delphinium glaucum & 13.2 & 2.3 & 11.8 & 56.7 & 22.8 & 2.6 \\
\hline Epibolium angustifolium & 4.7 & 4.0 & 4.3 & 79.0 & 18.2 & 3.1 \\
\hline Festuca sp. & 7.9 & 2.8 & 6.6 & 78.0 & 34.4 & 5.7 \\
\hline Fragaria virginiana & 8.9 & 4.9 & 7.3 & 38.0 & 18.9 & 3.8 \\
\hline Oxytropis splendens & 16.0 & 2.4 & 10.3 & 47.5 & 34.3 & 14.2 \\
\hline Solidago sp. & 8.8 & 4.0 & 7.0 & 49.3 & 31.5 & 12.5 \\
\hline Trifolium hybridum & 12.4 & 2.2 & 8.3 & 50.2 & 31.7 & 12.4 \\
\hline Zygadenus elegans & 8.7 & 4.3 & 8.6 & 38.3 & 28.6 & 8.2 \\
\hline Grasses & 11.2 & 3.5 & 7.0 & 56.1 & 32.3 & 3.2 \\
\hline Sedges & 8.1 & 3.5 & 5.0 & 55.8 & 30.8 & 2.9 \\
\hline Average & 10.8 & 3.6 & 7.2 & 53.6 & 27.8 & 6.8 \\
\hline \multicolumn{7}{|c|}{ Summer 1976 , browse food } \\
\hline Artemisia campestris & 10.2 & 4.1 & 6.8 & 33.7 & 29.6 & 17.4 \\
\hline Betula glandulosa & 15.1 & 8.2 & 4.1 & 36.2 & 15.2 & 7.3 \\
\hline Castilleja occidentalis & 8.4 & 4.4 & 14.5 & 58.6 & 34.5 & 23.1 \\
\hline Populus tremuloides & 12.1 & 8.4 & 4.3 & 45.0 & 17.6 & 10.0 \\
\hline Potentilla fructicosa & 10.3 & 4.4 & 11.6 & 34.3 & 21.3 & 8.6 \\
\hline Ribes sp. & 9.1 & 1.6 & 6.0 & 36.1 & 14.4 & 6.0 \\
\hline Rosa acicularis & 12.8 & 4.6 & 5.1 & 52.9 & 10.2 & 1.6 \\
\hline Rubus idaeus & 11.2 & 6.0 & 6.7 & 32.8 & 19.5 & 3.8 \\
\hline Salix glauca & 13.8 & 3.7 & 5.9 & 24.4 & 20.5 & 8.8 \\
\hline Salix sp. & 7.9 & 1.8 & 11.3 & 32.7 & 29.5 & 9.6 \\
\hline Shepardia canadensis & 17.8 & 6.4 & 9.0 & 19.4 & 16.4 & 5.2 \\
\hline Viburum edule & 10.4 & 9.2 & 6.4 & 35.1 & 15.7 & 5.9 \\
\hline Average & 11.6 & 5.2 & 7.6 & 36.8 & 20.4 & 8.9 \\
\hline
\end{tabular}

Winter 1976, non-browse food

\begin{tabular}{lcccccr} 
Grasses and sedges & 5.6 & 3.0 & 7.9 & 62.5 & 39.0 & 4.4 \\
\hline & Winter & 1976, browse & food & & & \\
Arctostaphylos uva-ursi & 4.77 & 6.92 & 3.26 & 24.84 & 18.40 & 7.92 \\
Dryas octopetala & 4.58 & 4.25 & 6.50 & 49.82 & 54.12 & 29.37 \\
Populus tremuloides/twigs & 7.10 & 10.20 & 3.05 & 42.97 & 30.71 & 12.73 \\
Populus tremuloides/bark & 4.75 & 6.90 & 5.29 & 29.70 & 27.86 & 10.47 \\
Populus balsamifera/twigs & 6.54 & 14.10 & 3.74 & 37.34 & 30.10 & 10.57 \\
Potentilla fructicosa & 5.27 & 4.26 & 0.61 & 54.59 & 51.38 & 20.14 \\
Salix sp. & 9.95 & 5.21 & 2.67 & 43.14 & 30.53 & 15.37 \\
Shepardia canadensis & 12.60 & 3.44 & 1.42 & 37.57 & 34.18 & 14.26 \\
Average & 6.9 & 6.9 & 3.3 & 39.9 & 34.7 & 15.1 \\
\hline
\end{tabular}

ether extract for balsam aspen shoots was unusually high, as much as $14.1 \%$ of dry weight.

Thus, during the growing season the nutritional value of browse is fairly high, a fact related to leaf content of this food. Browse contains more than minimal protein, but is nutritive value is lower than nonbrowse food. This is reflected by the fact, that the crude protein to 
ether extract ratio (which is a quality index of food for ruminants; Bobek, 1977) is 2.2:1 for browse and is $3: 1$ for grasses and sedges. In winter, the nutritional quality of both types of foods is reduced with a greater reduction in browse than in non-browse foods. In addition to the increase in fiber value, crude protein to ether extract ratio in browse was $1: 1$ while in non-browse food it was $1.9: 1$.

\subsection{Simulation of Body Weight Changes}

Consumption of the optimal diet (see material and methods) results in typical seasonal pattern of changes in the body weights of both sexes. The body weight of males was somewhat reduced during winter,
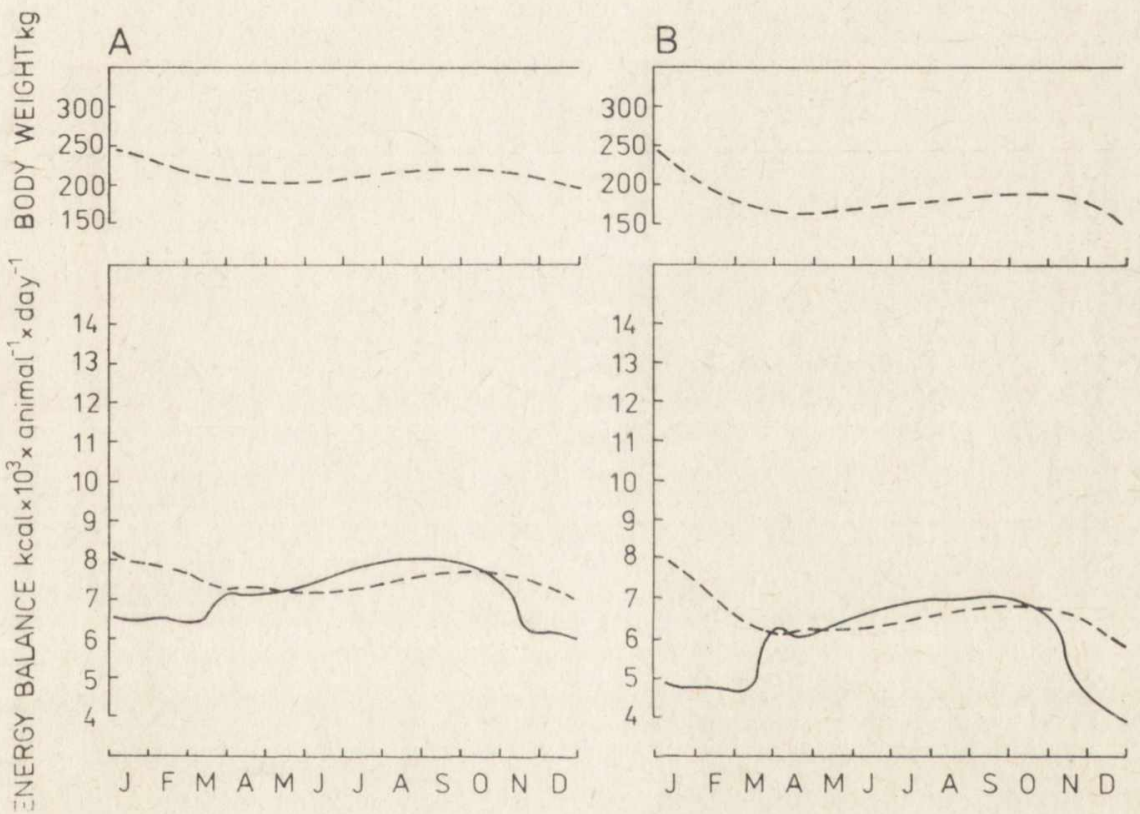

Fig. 1. Body weight, energy assimilated (solid line), and energy required (broken line) by male elk. A - Optimal food during summer and mixed one, i.e., 1/2 browse and $1 / 2$ optimal forage during winter. B - Optimal summer diet and all browse diet in winter.

however during the growing season this loss was quickly made up, and the annual fluctuation did not exceed $10 \mathrm{~kg}$ in each direction (Fig. 1). The simulated amplitude of weight change in male elk is probably underestimated because of liberal model parameters and ignoring rut fasting in bulls.

Females eating this diet gained weight during the winter due to embryo development but energy reserves were being depleted. Loss 
of energy reserves and thus weight loss was much more rapid after parturition during lactation (Fig. 2a). These was an $80 \mathrm{~kg}$ body weight fluctuation in females caused both by parturition and weight losses during lactation. The total yearly energy expenditure for males was 3,089 Mcal and for the females 3,568 Mcal of which 670 Mcal were for reproduction.

Another simulation was done under the assumption that animals ate only browse throughout the entire year. Such a diet would cause death in males between winter and spring when there is not enough time to
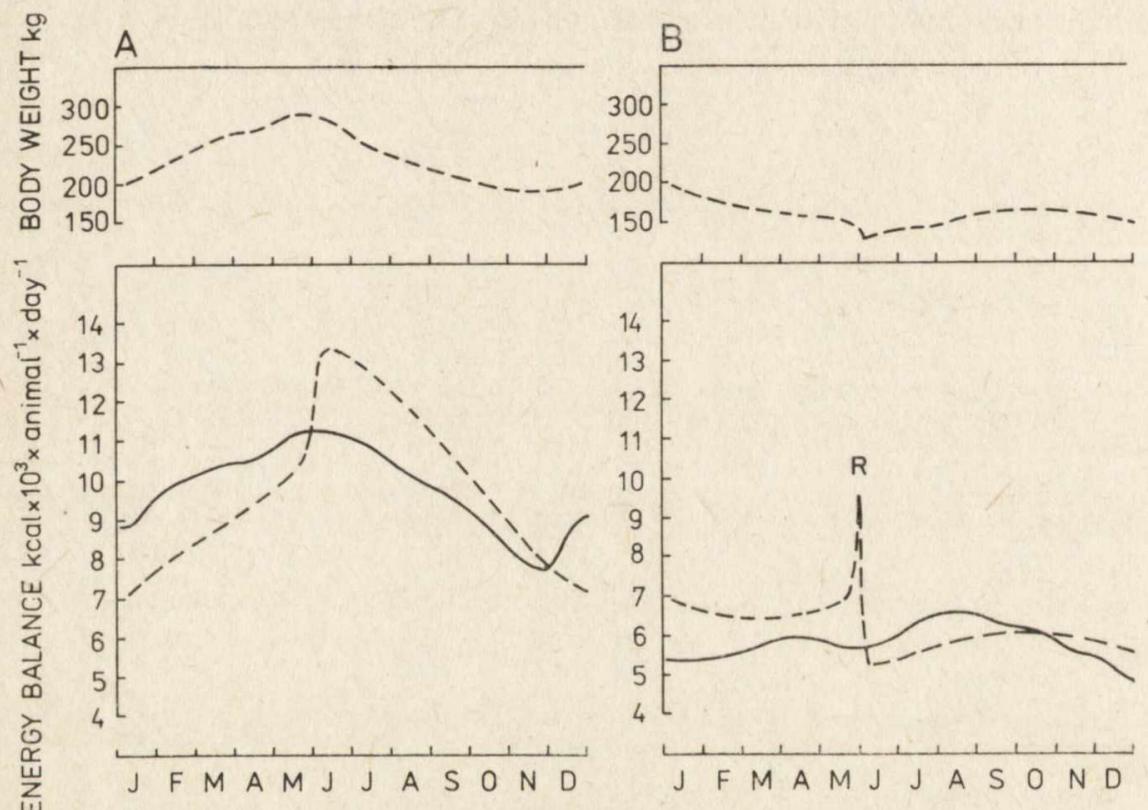

Fig. 2. Body weight, energy assimilated (solid line), and energy required (broken line) by female elk consuming for the entire year: A - Optimal diet, B - All browse diet. $\mathrm{R}$ - re-absorption of fetus.

activate energy reserves. This simulation predicts that females could survive on this diet only by re-absorbing embryos one month before parturition. This, however, does not appear to be physiologically possible at such and advanced stage of pregnancy. An abortion, however, could occur at that stage. Moreover, fetus reabsorption is triggered in the model by energy storage falling to an arbitrarily chosen value of $30,000 \mathrm{kcal}$. This value obviously affects the simulated moment of fetus re-absorption or abortion (Fig. 2B).

A simulation was then performed assuming that browse was the sole winter food (from November 15 to March 30) and that during summer animals consumed the "optimal" diet. Under this condition males lost 
$95 \mathrm{~kg}$ during the course of the year which seems physiologically impossiblè. On this diet females re-absorbed embryos but did not lose body weight, because subsequent energy requirements did not include the cost of lactation.

Further simulations were performed using the optimal summer diet and several variants of winter diet: a mixture of the "optimal" diet and $1 / 3,1 / 2$ and $2 / 3$ of browse. These mixtures were designed to represent different availabilities of grass, resulting from different snow depths. In each of these variants both sexes survived - males lost 34, 50 and $65 \mathrm{~kg}$ respectively in these runs. These appear to be realistic values. The pattern of weight loss for females was quite different. Females lost 60,50 and $30 \mathrm{~kg}$ respectively. From this it appears that poorer winter diet makes the subsequent recovery in body weight easier. This paradox results from the fact that an early cessation of lactation, resulting from winter malnutrition gives the female a longer period during the growing season during which she is able to regain her body weight (Fig. 2). The resulting malnutrition of calves, however, might be fatal.

\section{DISCUSSION}

Our model over-simplifies the bioenergetic process of the wapiti For instance, it does not consider the energy costs associated with male rutting behavior or antler growth. Energy costs of rutting can be a critical factor in winter survival of males. It is known, the animals lose some of their fat reserves during rut (Struhsaker, 1967; Flook, 1970) and since this occurs in September, repletion of fat reserves before winter is impossible. Therefore, survival of males might be even less than our model suggests.

Also, the equations used in this model are not satisfactory. Particularly, the equation for calf growth rate (4), equations (7) and (8) relating the digestibility and voluntary consumption of food to its composition, should be substituted by more dependable empirical formulas, because they are crucial for the model. The scarcity of available data forced us to use $A D L$ content as an indicator of digestibility, while $C W C$ or protein content (or both) would probably be better (cf. Weiner, 1975a, b). The model also ignores the potential utilization of protein as energy reserve.

In spite of these simplifications the model adequately describes the "boom-and-bust" bioenergetic strategy of large ruminants living in the northern hemisphere. This strategy depends on building appropriate 
energy reserves during the growing season and the systematic utilization of these reserves during the winter period when food is nutritionally inadequate. This is reflected in nature by the characteristic curve of body weight with an increase during summer and autumn, and a decrease during winter. This pattern is reproduced by our model.

In Banff, non-browse food is of higher nutritional value than browse food. Its availability, however is usually limited by heavy snow cover. The accessiblity of browse is less affected by snow cover, but the poor quality of this food results in a pronounced negative energy balance. Thus when browse is the only food available, animals which enter winter with largest fat reserves (in the model fat reserves are linearly related to body size) have the best chances for survival. Young animals are at a disadvantage too, because they have higher weight-specific energy requirements. This means that a severe winter will cause the greatest mortality among young animals and among mature individuals with inadequate fat reserves.

Over-winter survival of individuals does not ensure survival of an elk population. To remain in a steady state, the population must balance deaths with births. Easy access during the winter to dry grasses, which elk prefer for browse does not absolutely ensure reproductive success. Under laboratory conditions female elk fed low quality food lost $21 \%$ of their body weight, abortions were observed and some of the young were born prematurely and died soon after birth (Thorne, Dean \& Hepworth, 1976). This is in contrast to females which were fed concentrates and alfalfa and were able to gain weight and give birth to healthy young which survived. Still, a diet high in grass should enhance reproductive success as compared to a poorer diet consisting largely of browse.

The generality of the assumptions and functions in the model is also confirmed by an analysis of the population structure of elk living in Banff National Park. Information from 1944 to 1956 and from 1970 to 1975 indicated that the sex ratio of this population differs significantly from year to year. Changes are also seen in the number of calves per adult female during autumn (Green, 1957). If these data are correlated with the snow fall for the area (Lake Louise) during January, February and April both male-female ratio and the number of calves per adult female are negatively correlated with snowfall (Fig. 3, 4). This probably results from the fact that during the period when fat reserves of these animals are exhausted, an increase in snow cover not only prevents access to non-browse food but also delays the growing season. The result of this is re-absorption of the fetus and numerous abortions which results in lower proportions of calves in the population during 


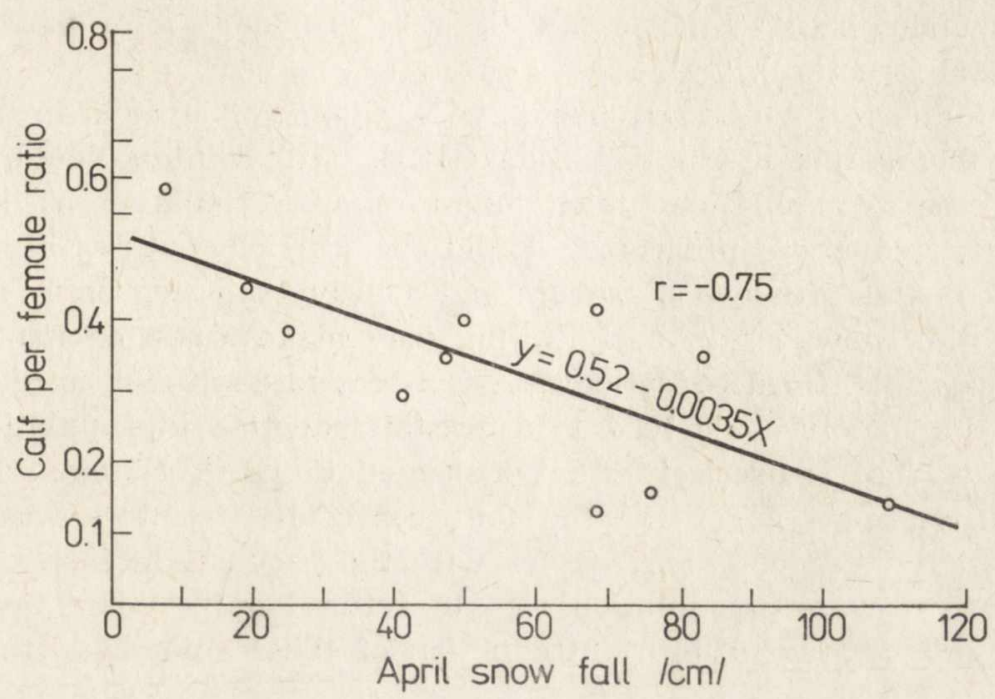

Fig. 3. Relationship between the number of calves per female and the total snow fall during April in Banff National Park. Calculations were based on data from Green (1950), Green (unpubl.), Flook (1970), Kunelius (unpubl.) and records of the weather station at Lake Louise.

autumn. Heavy snow is particularly disadvantageous to the males which, as a result of rutting, enter winter with lower fat reserves (Flook, 1970). Further, their forced reliance on browse is more detrimental than it

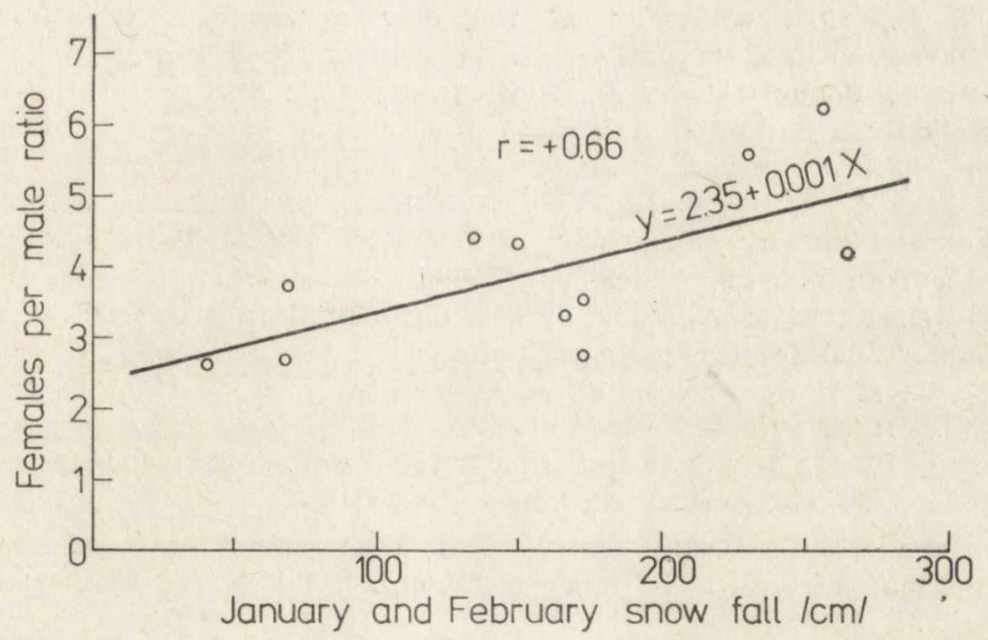

Fig. 4. Relationship between the number of females per male and the total snow fall during January and February. Calculations were based on data from Greeen (1957), Flook (1970), Kunelius (unpubl.) and records of the weather station at Lake Louise. 
is for females because the male's digestive efficiency is probably lower (see model structure).

To summarize, snow fall has a very significant role in regulating the number of elk in Banff National Park. Mild winters could lead to an increase in population which might require regulation by hunting. However, reduction programs should be carried out with caution. Winters in this area can be severe and a heavy snow cover or freezing rain on the snowpack in early spring may make access to non-browse food impossible. Herd reduction at a constant rate without consideration of climatic factors could lead to a drastic reduction in population size. It appears that is precisely what happened in Banff National Park in 1970-1974. Snow cover for the four consecutive winters was $43.5 \%$ higher than average. This, together with the previous intensive reductions, caused wapiti population size to return to the same level that existed immediately after reintroduction of these animals to the Park.

Acknowledgements: The authors are grateful to Dr. D. Swift, Dr. M. Boyce, Dr. V. Geist and Dr. W. Ross for their critical reading of the manuscript, and to Dr. R. Revel for the plant identification.

\section{REFERENCES}

1. Atman P., Kay R. N. B., Goodall E. D. \& Sharman G. A. M. 1974: The composition and yield of milk from captive red deer (Cervus elaphus L.). J. Reprod. Fert., 37: 67-84.

2. Bobek B., 1977: Strategies of roe deer management in various forest ecosystems. Proc. XIIIth Int. Congr. Game Biol.: 244-251.

3. Cohen Y., Robbins C. T. \& Davitt B. B., 1978: Oxygen utilization by elk calves during horizontal and vertical locomotion compared to other species. Comp. Biochem. Physiol., 61 A: 48-48.

4. Craighead J. J., Craighead F. C., Ruff R. L. \& O'Gara B. W., 1973: Home ranges and activity patterns of nonmigratory elk of the Madison Drainage Herd as determined by biotelemetry. Wildl. Monographs, 33: 6-50.

5. Flook D. R., 1970: A study of sex differential in the survival of wapiti. Canadian Wildlife Service Report Series, 11: 1-71. Ottawa.

6. Gates C., \& Hudson R. J., 1978: Energy costs of locomotion in wapiti. Acta theriol., 21: $365-370$.

7. Goering H. K. \& Van Soest P. J., 1970: Forage fiber analysis. Agricult. Handbook No. 579. Agricult. Res. Serv. USDA: 1-20.

8. Graham N. McC., 1965: Metabolism of the pregnant ewe and some effects of thermal stress. [In: "Energy metabolism", Ed. K. L. Blaxter]. Academic Press: $387-394$. London - N.Y.

9. Green H. U., 1950: The productivity and sex survival of elk, Banff National Park, Alberta. Can. Field. Nat., 64: 40-42.

10. Green H. U., 1957: Notes on the elk of Banff National Park, Dept. of Northern Affairs and National Resource, Canada. Mimeographed report. 47pp. 
11. Hafez Y. S. L. \& Dyer J. A., 1969: Animal growth and nutrition. Lea and Fibiger: $1-402$. Philadelphia.

12. Harper J. A., Harn J. H., Bentley W. W. \& Yocom C. F., 1967: The status and ecology of the Rosevelt elk in California. Wildl. Monographs, 16: $1-49$.

13. Kielanowski J., 1965: Estimations of energy cost of protein deposition in growing animals. [In: "Energy metabolism", Ed. K. L. Blaxter]. Academic Press: 13-20. London - N.Y.

14. Lloyd H., 1927: Transfers of elk for restocking. Can. Field Nat., 41: 126-127.

15. Maloiy G. M, (O. \& Kay R. N. B., 1971: A comparison of digestion in red deer and sheep under controlled conditions. Quart. J. Exp. Physiol., 56: $257-266$.

16. Moen A. H., 1973: Wildlife ecology. W. H. Freeman and Co.: 1-458. San Francisco.

17. Moen A. H., 1976: Energy conservation by white-tailed deer in the winter. Ecology, 57, 1: 192-198.

18. Nagy J. C. \& Regelin W. L., 1975: Comparison of digestive organ size of three deer species. J. Wildl. Manage., 39: 621-624.

19. Ogilve R. T., 1966: Ecology of vegetation in Banff National Park. National Parks Branch Workshop. 21 pp.

20. Perzanowski K., 1978: The effect of winter food composition on roe deer energy budget. Acta theriol., 23: 451-467.

21. Rattray P. V., Garret W. N., Meyer H. H., Bradford G. E., Hinman N. \& East N. E., 1973: Net energy requirements for growth of lambs age three to five months. J. Anim. Sci., 37: 1386-1389.

22. Rattray P. V., Garret W. N., East N. E. \& Hinman N., 1974: Efficiency of utilization of metabolizable energy during pregnancy and the energy requirements for pregnancy in sheep. J. Anim. Sci, 38: 383-393.

23. Richmond R. J., Hudson R. J. \& Christopherson R. J., 1977: Comparison of forage intake and digestibility by American bison, yak and cattle. Acta theriol., 22: $225-230$.

24. Robbins C. T., Moen A. N. \& Reid J. T., 1974. Body composition of whitetailed deer. J. Anim. Sci., 38: 871-876.

25. Robbins C. T., Cohen Y. \& Davitt B. B., 1979: Energy expenditure by elk calves. J. Wildl. Manage., 43: 445-453.

26. Salmon-Legagneur E., 1968: Prenatal development in the pig and some other multiparous animals. [In: "Growth and development of mammals. Eds. G. A. Lodge \& G. E. Lamming]. Butterwords: 158-191. London.

27. Staines B. W., 1969: Digestion of heather by red deer. Proc. Nutr. Soc., 28: $1-21$.

28. Struhsaker T. T., 1967: Behaviour of elk (Cervus canadensis) during the rut. Z. Tierpsychologie, 24: 80-114.

29. Swift D. M., Ellis J. E. \& Hobbs N. T., 1980: Nitrogen and energy requirements of North American cervids in winter - a simulation study. Proc. 2nd. Int. Reindeer/Caribou Symposium. 1979. Røros, Norway: 244-251.

30. Thorne R. T., Dean R. E. \& Hepworth W. G., 1976: Nutrition during gestation in relation to successful reproduction in elk. J. Wildl. Manage., 40: 330-335.

31. Weiner J., 1975a: Model of energy budget of an adult roe deer. Pol. ecol. Stud., 1: 103-119. 
32. Weiner J., 1975b: Zapotrzebowanie energetyczne sarn. (Energy requirements of roe deer). Ph. D. Thesis, Jagiellonian University, Cracow, $67 \mathrm{pp}$. [in Polish].

33. Weiner J., 1977: Energy metabolism of the roe deer. Acta theriol., 22: 3-24.

Accepted, March 7, 1983.

Bogusław BOBEK, Rick KUNELIUS i January WEINER

\author{
BUDŻET ENERGETYCZNY I STRUKTURA POPULACJI WAPITI \\ (CERVUS ELAPHUS NELSONI NELSON, 1902) \\ W PARKU NARODOWYM BANFF (KANADA)
}

\title{
Streszczenie
}

Opracowano model budżetu energetycznego wapiti. Model ten pozwala na określenie bilansu energetycznego zwierzęcia, poprzez porównanie bilansu zapotrzebowania energetycznego $\mathrm{z}$ konsumpcją energii, oszacowanej na podstawie skiadu poikarmu. Przy pomocy symulacji komputerowych wyliczono, iż zapotrzebowanie energetyczne pojedynczego dorosłego samca sięga 3086 Mcal, a samicy 3568 Mcal/ irok.

Z terenu Parku Narodowego Banff położonego w Górach Skalistych Kanady zebrano latem i zimą szereg gatunków żeru pędowego i roślin runa, które w tym rejonie stanowią potencjalny pokarm wapiti. Wykonano analizę wartości odżywczej tych gatunków, oceniając białko, wyciąg eterowy, popiół, zawartość ścian komórkowych $(C W C)$, ligniny $(A D L)$ i włókna $(A D F)$. Z uzyskanych wyników wyciągnięto wniosek, że niezależnie od sezonu żer pędowy posiada znacznie niższą wartość odżywczą niż rośliny runa (Tabela 1).

Następnie korzystając $\mathrm{z}$ opracowanego modelu budżetu energetycznego symulowano $\mathrm{w}$ komputerze różny skład diety wapiti. Z przeprowadzonych obliczeń wynika, że nadmierny wzrost żeru pędowego w diecie wapiti powoduje drastyczną obniżkę ciężaru ciała, resorpcje embrionów, poronienia, a także ewentualną śmierć zwierzęcia (Rys. 1, 2). Samce okazały się być bardziej wrażliwe na drastyczne pogorszenie składu diety.

Celem sprawdzenia czy opracowany model jest wiarygodny analizowano wieloletnią strukturę wiekową i płciową populacji wapiti w Parku Narodowym Banff. Duże opady śniegu redukujące w diecie wapiti udział roślinności runa, były dodatnio skorelowane $(n=0.66)$ ze śmiertelnością samców w populacji i wydatnie obniżały $(r=-0.75)$ dalszy przyrost populacji (Ryc. 3,4). Dowodzi to, iż opracowany model budżetu energetycznego dobrze odzwierciedla sytuację bioenergetyczną i jej wpływ na parametry demograficzne wapiti w naturalnych warunkach. 